\title{
State Terrorism: South \\ America during the 1970s. \\ A case of State Terrorism Transnationalization
}

\author{
Julio Lisandro Cañon Voirin* \\ juliolisandro.canon@gmail.com
}

\begin{abstract}
Resumo
Durante a década de 1970, por vez primeira na história política do Cone Sul, produziu-se a integração supranacional entre as diferentes ditaduras da região. Estas intensificaram a ação repressiva estatal, pondo em funcionamento uma maquinaria de guerra estatal contrarrevolucionaria, com um claro desejo de liquidação, que atingiu uma realização objetiva através do desaparecimento de pessoas e a disseminação do terror. Como resultante desse processo, que não conheceu fronteiras nacionais nem limites ideológicos, ficou a em massa violação aos direitos humanos; por outro lado e a partir disso, no campo das ciências sociais se empregou a conceptualização de terrorismo de Estado dantes de que sua precisão conceptual permitisse unicidade de critérios. Este artigo realiza uma reflexão teórico conceptual para avançar no entendimento dos mecanismos específicos de aparecimento, expansão e transnacionalização do terrorismo de Estado. Com o estudo concreto da chamada Operação Condor, que demonstrou cabalmente a integração das ditaduras de Argentina, Bolívia, Brasil, Chile, Paraguai e Uruguai.
\end{abstract}

\section{Palavras-chave}

Terrorismo de estado; ditadura; Cone Sul; Operação Condor

\section{Terrorismo de Estado: uma integração supranacional (América do Sul, durante os anos 70)}

\begin{abstract}
During the 1970s, for the first time in the political history of the Southern Cone, supranational integration between the different dictatorships of the region took place. These intensified state repressive action, putting into operation a counterrevolutionary state war machine with a clear desire for liquidation, which reached an objective realization through the disappearance of people and the spread of terror. As a result of this process, which knew no national boundaries or ideological boundaries, there was a massive violation of human rights; on the other hand, and from this, in the field of social sciences the conceptualization of State terrorism was used before its conceptual precision allowed for unicity of criteria. This article presents a theoretical conceptual reflection to advance the understanding of the specific mechanisms of the emergence, expansion and transnationalization of State terrorism. With the concrete study of the Operation Condor, which fully demonstrated the integration of the dictatorships of Argentina, Bolivia, Brazil, Chile, Paraguay and Uruguay.
\end{abstract}

\section{Keywords}

State terrorism; dictatorship; Southern Cone; Operation Condor 


\section{Introduction}

The following essay deals with a State Terrorism analysis as well as with the precise study of its development in South America during the 1970s, which became evident by means of a qualitative and deep change within the own notion of State.

It is known that the State holds the monopoly of legal violence and, in accordance with that power, it has every possible legal resource to increase repression measures supervised by coercion institutions. However, as it is the case presented in this essay, the State can release itself from the limitations associated with the rule of law, and according to particular intimidation purposes against political opponent (previously turned into political enemies), the State, in one way or another, can systematically carry out terrorist activities (Cañón, 2012). In the case we are about to tackle here, that change set up a new idea of repressive profile which characterized the different dictatorships until the 1960s.

The aim of this investigation is related to the social historical horizon of a region afflicted with a lasting hegemony crisis. The context and the worth mentioning social conditions of that time are the impossibility for the historical parties in power to make a long lasting political hegemony possible, as well as their inability to act as an integrating class and to perform actions that may increase their supportive basis. All those aspects are not indifferent to the process through which the Armed Forces failed to act as a leading figure of the political system to start fulfilling a decisive part in the relationships State/class and State/ society.

This study is based upon the idea that the new role conferred to the State and, within it, to the army, is connected with the prefiguration of a new kind of political power and with the performance of regressive economic and social measures which articulate a new mod- el of accumulation and reproduction of the capital. The deep and structural roots which explain it are to be found in the transnational character of bourgeoisie historically allied and dependent on central capitalism powers and on the way the army acted as a safeguard of such alliance.

The decisive role of the army in this process and its change of attitude towards a new kind of activity (the interior security and the war against an inner enemy) occurred under the influence of two military corpuses. On the one hand, the National Security Doctrine, regarded as a political ideological and cultural elite sympathizer of the U.S. capitalist interest, which meant an expanding domination on the part of that country since the second half of the twentieth century. On the other hand, the ideals of Modern War, theory of the counterrevolutionary action developed by the French colonial army after its experiences in both Indochina (1946-1954) and Algeria (1954-1962), represented a new definition of how military conflicts should be understood as it replaced the classic concept of confrontation among states with another kind of confrontation which was among individuals. It also changed the concept of fighting for territorial control by an ideological control of society. Between both doctrines there are, however, a lot of points in common. It is from those points in common that the premise supported and spread by such doctrines regarding the existence of an enemy striking inside of national societies comes out

While the army members received training in counter-insurgency techniques in both American and French academies, the most conservative and influential circles of South-American leading classes were considering a deep guideline revision of the political organization of their societies (Cañón, 2015). Both processes joined together, opening the way to the idea of the establishment of a state rationality based on inner security, and building a model of a constant alert State 
included within the principle of domestic war. From the scores of power, a new ideological conception was arranged aiming to articulate institutional mechanisms of both social and political discipline. The real State's strength -to control, follow and repress- increased. Security and intelligence were placed under army surveillance. Everything was subordinated to national security.

Although this idea fits in a specific period determined by the Cold War, it does not explain neither how or why they fought in imaginary battle fields (but with real, human beings made of flesh and bone) against a mythical entity, a terrifying enemy: the communisminspired subversion. It was a social construction that from a "we" saw the other one as an aggressor; crystallization of an exclusive way of thinking that viewed the other one not only by opposition but also in opposition: "When it comes to make up a fantastic monster, an ideological offensive always arises, followed by campaigns to destroy it. You cannot attack if the enemy is able to defend itself: it would be far too risky. But, however, if you feel confident that it can be overcome, you might knock it off soon and give another sign of relief afterwards" (Chomsky, 2005: 32).

The discursive construction of the subversive concept gradually colonized the institutional framework of nations, to such extent that they became the executers of a violence rationally aimed at the removal, the destruction or, at least, the weakening of those declared as enemies.

\section{Situation: from the coups to State Terrorism}

All along the twentieth century, most part of American nations were immersed in both constitutional and de facto government's succession, generally on account of coups favored and executed by the army of those countries. As for social sciences, inquiries were conducted to find out why the institutional development alteration reached the status of norm.

According to Alain Rouquié (1982), the LatinAmerican authoritarianism and the regularity of the coup allow us to consider those countries as militarized ones. Other important views are taken by Guillermo O'Donnell, who described the militarized countries of the region as bureaucratic and authoritarians. Those would be characterized, in O'Donnell' s (1972) opinion, by their tendency to impose a massive exclusion of the democratic participation of citizenships right at the time when they claim to be willing to achieve a wider modernization.

Alain Touraine is against approaches like O'Donnell's, considering them to be unsuitable for the American scene. On the contrary, he proposes the antipopular model of state. His reflections on the different ways of military interventions lead him to consider them as anti-popular dictatorships where the authoritarian exercise power and, unlike fascism, the purely repressive control over people replace the ideological and military mobilization. For Touraine (1982) the antipopular repression is the common factor that allows us to place all the authoritarian regimes in the American continent at the same level. These three works, focused on the authoritarian character of military regimes, created the core from which a lot of subsequent investigation started.

Other investigation lines have taken care of finding out the causal factor of military interventionism. Such autonomy would be the result of a process where the army is turning from temporary inspectors to work out particular crises to authorized parts of the nation interest (González Casanova, 1977). Such transformation would become a continental experience since the military regime held in Brazil, after the coup against president Joao Goulart (03/31/64), which turned out to be the first Latin-American country founded according 
to the ideas of the National Security Doctrine, in order to impose its viewpoint to the rest of the coup attempt supporters in Latin-American inland (Calvo, 1979). Consequently, a number of works devoted to the emergency of military dictatorships in the southern cone under the influence of the National Security Doctrine, such as those by Jorge Tapia (1980) in Chile and Brazil, Enrique Vázquez (1985) in Argentina, emphasized the reactionary and conservative root of South-American military bodies. As Prudencio García (1995) describes it, the army's autonomy is founded on the certainty of some army officers that they can and must intervene in major national policy problems.

One of the most clarifying efforts of understanding, but perhaps with less empirical development in connection with the emergency of dictatorships in Latin -America and its relationship with the socio-economic conditions is the work of the historian Perry Anderson (1988). His central idea lies in what he calls "populist inflexion", which is a consequence of a relationship between agricultural capital and industrial work. According to Anderson, the emergency of the dictatorships would be explained by its own function: traumatize the civil society with a big enough dose of terror, to frustrate any possible idea of social change from its core. He claims that all military regimes that appeared in Latin-America from the middle 1960s onwards were counterrevolutionaries and preventives, having as a main function behead and delete lefty parties, which did not coincide with the capitalist way of production. In this way, it added up a new element to define these military regimes, that is, having stipulated, as part of its reconstruction work, the reintroduction of a controlled capitalist democracy.

The brief analysis of most of the ideas about military interventionism allows us to start digging deeper in the analysis of state terrorism. In relation to this, it's important to emphasize that each and every investigation concerning this issue demonstrates the existing difficulties to provide a notion of understanding. According to Alex Schmid (1983), most of the definitions have a lot of elements in common which help us considering both nationwide terrorism and terrorism against the nation.

Adam Roberts (2002) points out how the definition of terrorism was at first meant to define dictatorships and terror governments to be, later on, used for the designating groups that, from the last years of the nineteenth century on, murdered political leaders and heads of state. In its first meaning, terrorism is close to the French revolution period where the state adopts the reign of terror ways (1773-1794). One of the first opinions about the terror government was given by Edmund Burke (1790) to whom the French revolutionary government ruled like tyrants by means of terror. Alexis de Tocqueville (1856) studied the relationship between violence and revolution, paying special attention to violence. All along the nineteenth century, the limited meaning of the word terrorism widened out to explain the exercise of every public demonstration of those groups interested in the promotion of their ideals by violent means.

In the last years, as Elias Padilla Ballesteros (2001) verifies, starting from all the different human right violation by state officers from several countries, the concept of terrorism of state has been used before its concept precision allows a unity of opinions. Nowadays, those difficulties have become tougher in view of the validity of a discreditable speech towards all those who try to oppose to the state activities; to those who are included within the definition of "terrorist", denying the right to both resistance and disobedience.

Boaz Ganor defines terrorism as "the premeditated use of violence or the threat to use it against civil population or civil objectives to obtain political benefits" (Ganor, 2001: 15). He excludes all those political 
actions which do not resort to violence and demonstrations, strikes or any other way of civil disobedience. It also excludes those violent actions against the army or the police, some actions from certain guerrillas or urban disturbances. In the same direction, Peter Waldmann's ideas distinguish between guerrillas and strictly speaking terrorism: "by terrorism I understand violent attacks against a political order prepared and organized from secrecy. Its purpose is to spread insecurity and fear, but also sympathy and predisposition to support" (Waldmann, 2007: 62).

Waldmann's operational approach, very similar to the French military logic about counterinsurgency, is complemented by his consideration of terrorism as a strategy of communication.

However, according to this author, there is not such a terrorism of state because he considers that terrorism comes from an idea against the political order, even though he admits that state elites can set up a reign of terror. As a consequence, for Waldmann, terrorism is a way of attacking the state and the established order; and terror is a state strategy to create panic and terror. Difference is then qualitative: "it depends on whether violence is used to keep the power or to change its situation" (Waldmann, 2007: 69). The objective of this essay prevents us from continuing along the reflexive path suggested by Waldamann, but nonetheless we must keep some elements in mind such as secrecy, fear and lack of safety.

Sharing a similar view, Hugo Frühling excludes state terrorism as a way of terrorism itself and suggests the following definition: "insurrectionary military-like strategy, used by small groups to preferably attack civil targets and whose main goal is to weaken the state and to prepare the conditions for its collapse" (Frühling, 1995: 7).

Rafael Calduch (1999: 339) notices some differences between social terrorism and state terrorism. For him, the main feature of the later is its straight application by state members. However, this characterization is incomplete, because it leaves an extensive range of possibilities aside such as the state developing national forces to carry out terrorist practices.

William Schulz clarifies that State Terrorism is not a new topic and, just like conventional terrorism, it has historically been constructed: "The reasons through which a ruling elite decides to give preference to some sorts of terror over others (for instance, crucifixion, instead of stoning; public execution instead of a private one; the disappearance of people more frequently than with the traditional political murder; the use of mental hospitals to replace jails) leads to another important aspect concerning this matter: the political psychology of state terrorism" (Schulz, 1990: 33).

This author brings up that average repression (law-abiding) and the state terrorism (violating national and international law) can be used within two different contexts: to defend a particular established system of production and appropriation, either for the expansion of some production relations, or their creation in places where they were not yet established.

Therefore, according to Schulz, the intensity in which the two forms of systematic repression are used depends on both the threat nature and dimension to which the system is exposed. In this way, ab elite within power resorts to terrorist methods whenever their ordinary repression ways and their hegemony controls prove to be ineffective to neutralize the threat. The State Terrorism can actually act in two different ways: directly, by means of agencies inside the state itself; indirectly, providing substitute entities (proxy entities) such as other states or other groups and individuals.

Regarding the aforementioned view, Miguel Bonasso distinguishes between terrorism and State Terrorism. In Bonasso's words, “terrorism involves groups of people or individuals who lack the repressive power 
of the state and use violence to express their opposition to that power, trying to undermine it" (Bonasso, 1990: 9). On the other hand, State Terrorism involves an ideological and political framework of the legal repression and appeals to unconventional methods, both extensive and intensive, to annihilate political opposition and social protest demonstrations, whether they are armed or disarmed (Bonasso, 1990: 10).

From a different perspective, Ernesto Garzón (1990) analyses the concept of State Terrorism taking into account its real legitimacy and its ethical illegitimacy. According to Garzón, there is a sum of elements which must be present in the exercise of State power to be considered terrorism of state. The existence of a vertical war with an enemy infiltrated in every area of society, that works a part of an international network whose aim is the elimination of accepted values by those in power. The imprecise delimitation of punishable actions and elimination of any judicial process in order to determine the existence of a crime; the clandestine imposition of measures of national sanction prohibited by the legal order officially proclaimed (tortured and homicides, among others). The unclear application of violent measures of liberty, property or life loss, disregarding in many cases the identity of the addressee of such measures and of the actions or omissions of which they might be held responsible; the use of violence on innocent people. Actually, this helps to strengthen the efficiency of terror; to fill the population with the real fear that, under mortal circumstances, nobody is safe from the arbitrary coercion by government members.

All that removes the idea of transgression from the legal system, so everybody can be a transgressor. This ambiguity about who are the addressees of the coercive measures and about the unclear definition of the pursuit groups, aims to raise fear and to impose intimidation. The mixture of these features, helps Ernesto
Garzón formulate the following definition of terrorism of state: "The State Terrorism is a form of state power exercise whose rule recognition allow or/and impose, with the purpose of creating wide-spread fear, the clandestine application, unpredictable and unclear, also to people clearly innocent, of coercive measures forbidden by the proclaimed legal system. This hinders or declares legal activity null and turns the government into an active agent eager to be in power" (Garzón, 1990: 147)

Wrapping up his definition of State Terrorism, he refers to the most important elements, from an institutional point of view: "An ideological organization whose core is a dogma, an idea useful as an absolute guideline, unquestionable, and handy as an excuse to destroy everything that goes against it. An efficient team of propaganda to account for the measures applied, resisting and stigmatizing opposite positions. The culture of the own image as a compensation for actions of cruelty: elimination of the self-criticism capacity by means of the machinery of inner discipline" (Garzón, 1990: 147-149).

All these elements can be found in the views, developed with unquestionable care and intellectual originality by Hannah Arendt: "terror in a totalitarian government is no longer a simple way to abolish opposition [...] its main goal is to make possible that the strength of nature (Nazism) or history (Marxism) runs freely along mankind without stumbling against any spontaneous action [...] It is this movement the one that distinguishes mankind enemies against who spark off terror, an no action or opposition can be allowed that hinders the elimination of the so-called enemyobjective of history or nature, of class or race. The guilt and the innocence become meaningless notions; guilty is he who stands in the way of natural and historical process $[\ldots]$ terror, as an execution of a movement law whose last aim is not people's welfare or one single 
person's interest but the rebuilding of mankind. It removes individuals in favor of the species, sacrifice the parts to support the whole $[\ldots]$ at the same time as logic, regarded as a movement of thought, rather than as a necessary thought control, is applied to an idea, this idea becomes a premise [...] as terror is needed to avoid that, with the birth of any new human being, a new start arises, making himself/herself heard, likewise, the coercive strength of logic is mobilized to prevent everybody from starting to think that, as the freest and purest of all human activities, is well and truly the opposite of the mandatory deduction process [...] what kind of basic experience in the social life of men pervades a form of government, the essence of which is terror and whose principle of action is the logic of ideological thought" (Arendt, 1998: 372-373; 376-379).

In this recap, it remains noteworthy the reference to the classic Eduardo Luis Duhalde's work. By means of different pieces of evidence, he succeeded to expose the model used in the military concentration camps during Argentine military dictatorship (19761983) where prisoners' personality destruction was the main target by the systematic use of both physical and moral torture. The setting up of State Terrorism was achieved, in Duhalde's words, by the systematic application of threats and reprisals in order to impose obedience (Duhalde, 1983).

Alexander George developed the theory of the so-called "global parallelism", which means the use of repressive mechanisms considered illegal even within each country's legislation; and a consistent clandestine application of repressive actions. As for George, the concept of State Terrorism implies that: "A state, seeking protection in the legitimacy of its actions, clandestinely and outside the law uses the same procedures that terrorist groups apply to scare any given citizenship and, by doing so, it reaches either social, political or military objectives, or even promotes behaviors that would not be achieved any other way" (George, 1991: 30).

In several approaches to the matter in question, Noam Chomsky has brought up the disagreement inexistence as far as terrorism definition is concerned. From what Chomsky reports, the word refers to the threat or to the use of violence, generally, for political purposes and against non-combatant civil citizens. In Chomsky's view, both State and individual terrorism depend on the source of planning and operation, or it is a mixture of them, when the individual terrorism operates under state orders or under its direction and support (Chomsky, 2002).

Taking reflections on investigations described so far as a starting point, the examination of several sources and the approaches stated in previous works, we will as well try to outline the typical concepts of State Terrorism. Such notion should contain: the use of repressive force against civil population by a State, fostered by political objectives, as a reaction against the interference of cultural values considered to be alien to the country tradition.

Bearing in mind what has been previously mentioned, it would be worth referring to such things as the systematic use of policies and practices, authoritarian and repressive by a State in accordance with some objectives to reorganize society. The execution of those policies can be carried out directly, by official staff; or indirectly, by means of agents unconnected with the State, but whose actions meet the orders of the state. Regardless of who the executor might be, the reason that causes its need lies in the wish to impose models of behavior desirable from the top authorities willing to eliminate from the social relations scene the behaviors considered unwelcomed and the programs which aim to modify established order. A discipline project got started using clandestine practices whose execution can even try to remain hidden. Starting a first series of up- 
setting situations for the social community by the state whose main function should be the security of citizenship- that state turns into one that disregards people's security and makes an illegal use of violence. State Terrorism not only characterizes itself by actions of state violence pursuit, but also by establishing a general feeling of fear in the population.

\section{The entente of terror, the Condor Operation}

Until the middle 1960s, the South-American military governments in force adopted the typology of a temporary authoritarian regime. Such regimes did not reject democracy as a way of social organization of the country and did not try to change the nature of the state itself, only a momentary interruption of both political and social liberties of their respective republican regimes and increase of repressive actions.

However, by the end of the 1960 s, and under the influence of both American and French policies that emphasized the need of a massive political will to face an inner enemy looking for a situation of vulnerability in safety, a doctrinal change began to be build according to the profile of the military interventionism, assuming ideas that were against the main basis of a democracy state. It was considered that the principle of legality, the respect to the essential content of basic rights and the jurisdictional control of the abovementioned rights, limited the power of the state to guarantee the security of the society. Therefore, a new state model was arranged, the National Security State, a peculiar form of State of exception which granted to the army the power to carry out the eradication of the sub- version and the rearrangement of the nation (in the case of Paraguay, with a dictatorship prevailing since 1954, a change took place in the practices; in Brazil the model that turned out to be the 1964 coup was intensified; and in Argentina it happened even before the army took real control of the state) ${ }^{1}$.

The strategy of destruction was developed in a nationwide scale with a repressive integration of regional character: the Condor Operation. This coordinated action, whose aim was not just to eradicate subversion, understood as the killing of people considered to be subversive, but also all kind of thought tending towards the free exercise of criticism.

As Stella Calloni claims, the discovery of the so -called Archives of Terror ${ }^{2}$, allowed the understanding of the role of dictatorial governments and also the part of CIA and another U.S. Institutions in the use of the idea of the National Security Doctrine by the different dictatorships (Calloni, 1999). This is something that Patrice McSherry worked on lately; in a way, she takes Perry Anderson's hypothesis about the social classes struggle in the south cone of Latin America and establishes a relation with the action of the army in some countries that have been historically against each other (McSherry, 2009).

The documents of the aforementioned corpus actually allow the reconstruction of the basis and the repressive methodology of Condor Operation. Its detailed description can be found in the cable sent by the FBI special agent, Coroner Robert Scherrer (assigned in different US diplomatic quarters and that, from 1972, was the legal assistant in the US Embassy in Buenos Aires) to the FBI director: "'Operation Condor' is the code name for the collection, exchange and storage of

\footnotetext{
${ }^{1}$ Giorgio Agamben (2004), understands and bases State of Exception "allows for the physical elimination not only of political adversaries but of entire categories of citizens who for some reason cannot be integrated into the political system" (Agamben, 2004, p. 25).

${ }^{2}$ The Archives of Terror were found on December 22, 1992. URL http://www.gwu.edu/ nsarchiv/NSAEBB/NSAEBB239a/index.htm [accessed 12 january 2010].
} 
intelligence data concerning so-called 'leftists,' communists and Marxists, which was recently established between cooperating intelligence services in South America in order to eliminate Marxist terrorist activities in the area. In addition, 'Operation Condor' provides for joint operations against terrorist targets in member countries of 'Operation Condor.' Chile is the center for 'Operation Condor' and, in addition to Chile, its members include Argentina, Bolivia, Paraguay, and Uruguay. Brazil also has tentatively agreed to supply intelligence input for 'Operation Condor'. The members of 'Operation Condor' that show the most enthusiasm to date have been Argentina, Uruguay and Chile. The last three countries have engaged in joint operations, primarily in Argentina, against the terrorist target. During the week of September 20th, 1976, the members of the Secretary of Information of the Argentinian State together with the Uruguayan intelligence service developed actions against the Uruguayan terrorist organization OPR-33 in Argentina. The OPR-33 has been eliminated $[\ldots]$

According to what has been informed, a third and very secret phase of the 'Condor Operation' had to do with building special teams in each country in order to perform operations such as murders of terrorists or of civilians who support their organizations. For instance, when a terrorist was identified as such, or a collaborator in a member country was discovered, a special team was sent to locate and watch the target. When the location and surveillance operation was finished, a second team from "Operation Condor'" would be dispatched to carry out the actual sanction against the target. Special teams would receive false documentation from member countries of 'Operation Condor' and were integrated exclusively by individuals from one or more member nations of 'Operation Condor'. European countries, specifically mentioned for possible operations under the third phase of 'Operation Condor', were France and Portugal."

A secret combined operation to exterminate enemies (lefties, communists, Marxists) enemies in common. Yet, the elimination required a previous step: the construction of the enemy itself. Enemies were identified as main figures of a dehumanization process, which lost the characteristics of human beings and, therefore, should be eliminated, but not only as a result of a ruthless and illegal repression but also in view of a new future role for the State. The projection of a new social order, of a new State, based upon the importance of the order and exclusion, colonized the political organization, going beyond the repressive legislation, reaching both education and organization of culture (Cañón, 2014).

The beginning of this process systematization can be placed in the $1^{\circ}$ Course of CounterRevolutionary War (Buenos Aires, 1961). Its purpose was to instruct military officers in the planning, management and execution of the counter-revolution. The program included the study of Marxist philosophy, the methods of penetration into society (infiltration) and techniques to both prevent and fight communism. The opening words of the course supervisor, General Turolo, concerning objectives, speak for themselves: "the study of the fighting methods against the biggest enemy of our way of living, communism" ${ }^{4}$. As for the Lieutenant General Poggi, Commander in chief of the Argentine army, the course symbolized the unity of the whole American continent "to protect ourselves against any

\footnotetext{
${ }^{3}$ This cable is from the FBI's legal attaché in Buenos Aires, Robert Scherrer. For more than two decades, it was almost the only released U.S. document that mentions Condor, and has been widely quoted in books and articles. URL http://www.gwu.edu/ nsarchiv/NSAEBB/NSAEBB8/ch23-01.htm [accessed 4 september 2014].

${ }^{4}$ Clarín, 3 october 1961. (Cited in Cañón, 2012b, p. 14)
} 
danger, from inside or from outside". 5

The Inter-American military conferences constituted an exceptional place for this process to get consolidated and, from 1960 onwards, they gathered annually in order to promote continental defense measures. In 1973, the Brazilian general, Breno Borges Fortes, made an evaluation of them: "We already have a number of achievements perfectly consolidated which are developing rapidly, such as the bilateral intelligence conferences and the conferences of the communications officers in command of the American armies that have already created a permanent commission of military communications (for its Spanish acronym, COPECOMI) and the settings up of the Inter-American military communications network (for its Spanish acronym, RECIM). We can also mention as a positive achievement of the above mentioned conferences the extension of students interchange inside the military schools of our countries, as well as military enlistments in friendly countries armies."

On the other hand, if we consider the thematic main point that concerned the American Armies Conference members from its creation in 1960 until the 1983 conference; it can be observed how Marxism turned into a military, political, social and cultural problem. With these conferences as a background, the concept of ideological borders appeared. During the V Conference (West Point 1964), the Argentine representative, Major Chief in the Army, Lieutenant Colonel Juan Carlos Onganía, showed what was lately known as West Point Doctrine ${ }^{7}$.
On this basis, surely backed by both national security and modern war ideals, a military ideology arose which was centered on the concept of a third world war, the bipolarity of world blocs, the combination of conventional and unconventional wars, the continental defense of America against an aggressive ideology of communism and the confrontation against the inner enemy ${ }^{8}$.

All these elements can be found in the counterrevolutionary coordination that supported the Condor Operation. The draw up of this entente of terror took place in the First National Intelligence Business Meeting in Santiago de Chile (November, December 1975). The representative members of Argentina, Brazil, Chile, Paraguay and Uruguay agreed that their countries "were being politically, economically and military attacked from both inside and outside their frontiers", and that until that moment they had faced that reality "fighting separately or at best either with bilateral agreements or well-mannered understandings". In this meeting they proposed to fix that situation by bringing the security coordination system into operation, "in general terms, something similar to what INTERPOL has in Paris, but wholly devoted to subversion." In a practical way, it supposed a major step in the transnational repressive integration and in the control of the actions focused on destroying subversion which "does not recognize neither frontiers nor nations and let infiltration get inside all levels of the nation life." ${ }^{10}$ As soon as the agreement was reached, repression had no longer limits nor frontiers.

\footnotetext{
${ }^{5}$ Clarín, 3 october 1961. (Cited in Cañón, 2012b, p. 14)

${ }^{6}$ La Opinión, 19 october 1975.

${ }^{7}$ See Cañón, 2012, 2012b, 2014.

${ }^{8}$ It should be noted the work of the War Colleges of each country, Pan-American Conference, Organizatin of American State, Inter-American Defense College, Conference of American Armies. All of them made the Soviet Union and communism the greatest threat to the status quo of the continent.

${ }^{9}$ Primera Reunión de Trabajo de Inteligencia Nacional. Santiago de Chile, 29 october 1975. Fotograma 00022F0153.URL <http://www.gwu.edu/ $\sim$ nsarchiv/NSAEBB/NSAEBB239b/PDF/19751000\%20Primera\%20reunion\%20de\%20Trabajo\%20de\%20Inteligencia\%20Nacional.pdf $>$ [accessed 11 february 2010]

${ }^{10}$ Primera Reunión de Trabajo de Inteligencia Nacional. Santiago de Chile, 29 october 1975. Fotograma 00022F0153. URL <http://www.gwu.edu/ $\sim$ nsarchiv/NSAEBB/NSAEBB239b/PDF/19751000\%20Primera\%20reunion\%20de\%20Trabajo\%20de\%20Inteligencia\%20Nacional.pdf $>$ [accessed 11 february 2010].
} 
They portrayed subversion as bearer of destructive project of both values and western and Christian principles: "Subversion for some years now can be found in our continent supported by political-economic ideas which are essentially against History, Philosophy, Religion and the costumes of the countries in our hemisphere."

After the first meeting, there was a second one in which representatives from every country belonging to the entente gathered together reunited in Buenos Aires (December 1976) to revise past actions and talk about future plans. The main subject of the agenda was operations planning "against lefty groups and extremists (...) to fight terrorism and subversion." ${ }^{11}$ During the year that went by between both meetings, the argentine coup occurred (March 1976). Argentina was the only member country of Condor Operation whose State power was not yet directly controlled by the army. However, we must not ignore the colonization of the repressive machinery by terrorism's own ways; its clear indication is the existence of semi-official force (consisting of members of the security forces and financed by the Social Welfare Ministry), the Argentine Anti-Communist Alliance, that ever since 1973 had carried out 2000 political murders (Amnistía Internacional, 1976), and the exercise of the repression executed in the Independence Operation "so as to destroy the subversive element in the bud" (Decreto número 261/1975). ${ }^{12}$

By the time all countries were involved in the combined repression under a military ruler, the US State Department contacted the American ambassador in Buenos Aires to inform him: "You are aware of a se- ries of reports on "Operation Condor". The coordination of security and intelligence information is probably understandable. However, government planned and directed assassinations within and outside the territory of Condor members."13

The existence of such units as the one in Paris, and the disappearances of Argentine, Brazilian, Bolivian, Chilean, Paraguayan and Uruguayan citizens in far off countries, demonstrate a persecutory offensive of pursuit and control with an exemplary pedagogy as a message. The strategy which distinguished that operation comprises a directionality of subjection, of subjugation by means of fear. The clandestine imprisonments, the systematic torture, the murder, the pursuit are all part of a political tactic, a tool of control (Foucault, 1987) that goes beyond a number of spread facts: violence and State Terrorism are the core of logic of power.

\section{To sum up}

The problems and objectives stated in this essay were developed by means of a historical reconstruction, during which an analytic follow up of the specific part of any process was favored, its translation as a conception and sociopolitical practice which was presented in a rational, elaborated and articulated project.

The projection and subsequent colonization of the logic claiming that the constitutional and legal mechanisms were less and less efficient to keep security, as well as the multiplication of restriction, control, and the repressive practices to holdback, stop or violently punish the political and social actions of subver-

\footnotetext{
${ }^{11}$ Opiniones sobre la Operación Cóndor. 18 april 1977. URL <http://foia.state.gov/documents/Pcia/9d23.pdf> [accessed 16 february 2010].

${ }^{12}$ Decreto número 261/1975, 5 february; ordering execute military operations necessary for the purposes to neutralize and /or destroy the actions of subversive elements acting in Tucumán province. And decreto 2.772/1975, 6 october; by which orders execution of military operations waged and Security to remove or destroy the action of all subversive elements the territory of country.

${ }^{13}$ Despacho inmediato a: Chile, Argentina, Bolivia, Paraguay, Uruguay. 18 de agosto de 1976. Departamento de Estado de EE.UU. URL <http:// www.gwu.edu/ nsarchiv/NSAEBB/NSAEBB312/5_19760823_Operation_Condor.PDF> [accessed 11 february 2010]
} 
sion are the core from where the new model of State was established. The tool of State coercion incorporates their traditional tasks (public and legal), other ones of clandestine nature, with massive crime and terror as a fundamental method. The component of secrecy had as its objective a strong intimidator factor, the attack on some groups extended on the whole community. That is to say, the whole community became the addressee of an intimidator action in which terror achieved transcendence as a way of social control by means of fear (Duhalde, 1983).

The intensity and the political power with which state terrorism was created and the nature of the searched transformations turn it into part of a program of total restructuration of the social organization. Unlike what happened in the constitutional order interruptions, during which the rights and the civil and political liberties were suspended, the complete re-foundation of the society became a goal under the protection of State terrorism.

Even though each national process has its own feature that responds to the actors and elements that intervene, at the moment when persecutory violence of State was practiced, we must not forget the regional integration. The repressive and disciplinary strategies of the State Terrorism as part of a security policy that ended up in a counterrevolutionary action means a redefinition of spatial parameters. The transnationalization of State Terrorism, that is, the expansive and international character of a persecutory and stigmatic logic that, in terms of the Southern cone, meant the establishment of ideological frontiers and made the army coop- eration possible.

To sum up, in an attempt to discipline and organize each one of the national societies, the different dictatorships used the organic, systematic and stateowned repression. By means of ruthless and sophisticated ways, they tried to achieve a submission to hierarchic order. For the first time in the political history of the southern cone, a machinery of counterrevolutionary State war was brought into operation whose most significant feature was the supranational coordination; the cooperation of the army and the security intern of domestic security; with a clear killing eagerness, which reached an objective realization through the disappearance of people and the dissemination of terror beyond national frontiers and ideological limits.

Once the goal was established, killing off the other, that is, guilty of subversion and where it was murdering the only thing they were after, the duty carried out justified the means. The justification simply lies in the victory against the negative concept of the other. Some of the consequences of this attitude are unpredictable since the State part is defined in an exclusive way whose aim becomes incompatible with everybody else's aim. They get rid of individuals (subversive) for the sake of nation, which Arendt defines as manufacturing humanity. That would mean the achievement of a cultural and social succeeding in unity: people with different and disintegrated wills, with heterogeneous goals gather together with a unique aim, with a unified view of the world and wishing the same future (Gramsci, 1977, pp. 388-396). 


\section{References}

ANDERSON, Perry. Democracia y dictadura en América Latina en la década del '70. Cuadernos de Sociología 2. 1988

AGAMBEN, Giorgio. Estado de Excepción, Homo sacer, II, I. Buenos Aires: Adriana Hidalgo, 2004.

ARENDT, Hannah. Los Orígenes del Totalitarismo. Buenos Aires: Taurus, 1998.

BURKE, Edmund. Reflexiones sobre la Revolución Francesa. Madrid: Ediciones Rialp, 1989 [1 $1^{\circ}$ edición en inglés de 1790]

CALDUCH, Rafael. Dinámica de la Sociedad Internacional. Madrid: Centro de Estudios Ramón Areces, 1993.

CALLONI, Stella. Operación Cóndor: los Años del Lobo. Buenos Aires: Continente, 1999.

CALVO, Roberto. La Doctrina Militar de la Seguridad Nacional. (Autoritarismo político y neoliberalismo económico en el Cono Sur). Caracas: Universidad Católica Andrés Bello, 1979.

CAÑÓN, Lisandro. Terrorismo de Estado y Política Educativa: Argentina (1976-1983). Santiago de Compostela: Universidad de Santiago de Compostela, 2012.

CAÑÓN VOIRIN, Julio Lisandro. El discurso cultural ideológico de orden. Argentina 1955-1983. In Otras Voces, Otros Ámbitos: los Sujetos y su Entorno. Nuevas Perspectivas de la Historia Sociocultural, Vicent BELLVER LOIZAGA, coord. Valencia: Universidad de Valencia, 2015.

CAÑÓN VOIRIN, Julio Lisandro. La guerra revolucionaria en la perspectiva de las FF.AA. Argentinas. Naveg@mérica 9, 2012b.

CHOMSKY, Noam. El nuevo humanismo militar: las lecciones de Kósovo. México: Siglo XXI, 2002.

Chomsky, Noam, SCHULZ, Wlliam, BONASSO, Miguel. Terrorismo de Estado. Navarra: Txalaparta, 1990.

FOUCAULT, Michel. Vigilar y Castigar. México: Siglo XXI, 1987.

FRÜHLING, Hugo. El Estado frente al Terrorismo. Santiago de Chile: Atena, 1995.

GANOR, Boaz. Premisas Fundamentales para Combatir el Terrorismo. Herlzliya: Instituto Internacional de Políticas para el Contra-Terrorismo, 2001.

GARCÍA, Prudencio. El Drama de la Autonomía Militar: Argentina bajo las Juntas Militares. Madrid: Alianza Editorial, 1995.

GARZÓN VALDÉS, Ernesto. Filosofía, Política, Derecho. Valencia: Universitat de Valencia, 2001.

GEORGE, Alexander. Western State Terrorism. Cambridge: Polity Press, 1991.

GONZÁlEZ CASANOVA, Pablo dir. América Latina: Historia de Medio Siglo. México: Siglo XXI, 1977.

GRAMSCI, Antonio. Antología. México: Siglo XXI, 1977.

GRAMSCI, Antonio. Cuadernos de la Cárcel, Tomo V. México: Era, 1999.

MCSHERRY, Patrice. Los Estados Depredadores: la Operación Cóndor y la Guerra Encubierta en América Latina. Santiago de Chile: LOM, 2009.

O’DONELL, Guillermo. El Estado Burocrático Autoritario. Triunfo, Derrotas y Crisis. Buenos Aires: Belgrano, 1972.

PADILla BAlleSteros, Elías. La Memoria y el Olvido. Detenidos Desaparecidos en Chile. Santiago de Chile: Orígenes, 2001.

ROBERTS, Adam. Can we define terrorism?. Oxford Today, 14, 2, 2002.

ROUQUIE, Alain. L'État Militaire en Amérique Latine. París: Seuil, 1982.

SCHMID, Alex. Political Terrorism. A Research Guide to Concepts, Theories, Data Bases and Literature. Amsterdam: Nort-Holland Publishing Company, 1983. 
TAPIA VÁLDES, Jorge. El Terrorismo de Estado: La Doctrina de la Seguridad Nacional en el Cono Sur. México: Nueva Imagen, 1980.

VÁZQUEZ, Enrique. PRN. La Última. Origen, Apogeo y Caída de la Dictadura Militar. Buenos Aires: EUDEBA, 1985.

TOCQUEVILLE, Alexis de. El Antiguo Régimen y la Revolución. Madrid: Ediciones Istmo, 2004.

TOURAINE, Alain. América Latina: Política y Sociedad. Madrid: Espasa-Calpe, 1982.

WALDMANN, Peter. Guerra Civil, Terrorismo y Anomia Social: el Caso Colombiano en un Contexto Globalizado. Bogotá: Norma, 2007.

Submissão: 07/07/2017

Aceite: $29 / 12 / 2017$ 